Theatre Research in Canada

Recherches théâtrales au Canada

\title{
Drama and the Liberal Arts at the University Level: Connecting Present, Past, and Future
}

\section{Moira Day}

Volume 39, Number 1, 2018

URI: https://id.erudit.org/iderudit/1055472ar

DOI: https://doi.org/10.7202/1055472ar

See table of contents

Publisher(s)

Graduate Centre for the Study of Drama, University of Toronto

ISSN

1196-1198 (print)

1913-9101 (digital)

Explore this journal

Cite this document

Day, M. (2018). Drama and the Liberal Arts at the University Level: Connecting Present, Past, and Future. Theatre Research in Canada / Recherches théâtrales au Canada, 39(1). https://doi.org/10.7202/1055472ar

All Rights Reserved (C) Theatre Research in Canada / Recherches théâtrales au Canada, 2018
This document is protected by copyright law. Use of the services of Érudit (including reproduction) is subject to its terms and conditions, which can be viewed online.

https://apropos.erudit.org/en/users/policy-on-use/ 


\section{Drama and the Liberal Arts at the University Level: Connecting Present, Past, and Future}

MOIRA DAY

At the University of Saskatchewan, the oldest Drama Department in the British Commonwealth has been wrestling with the balance between Drama as professional training and Drama as academic/liberal arts education since 1945 .

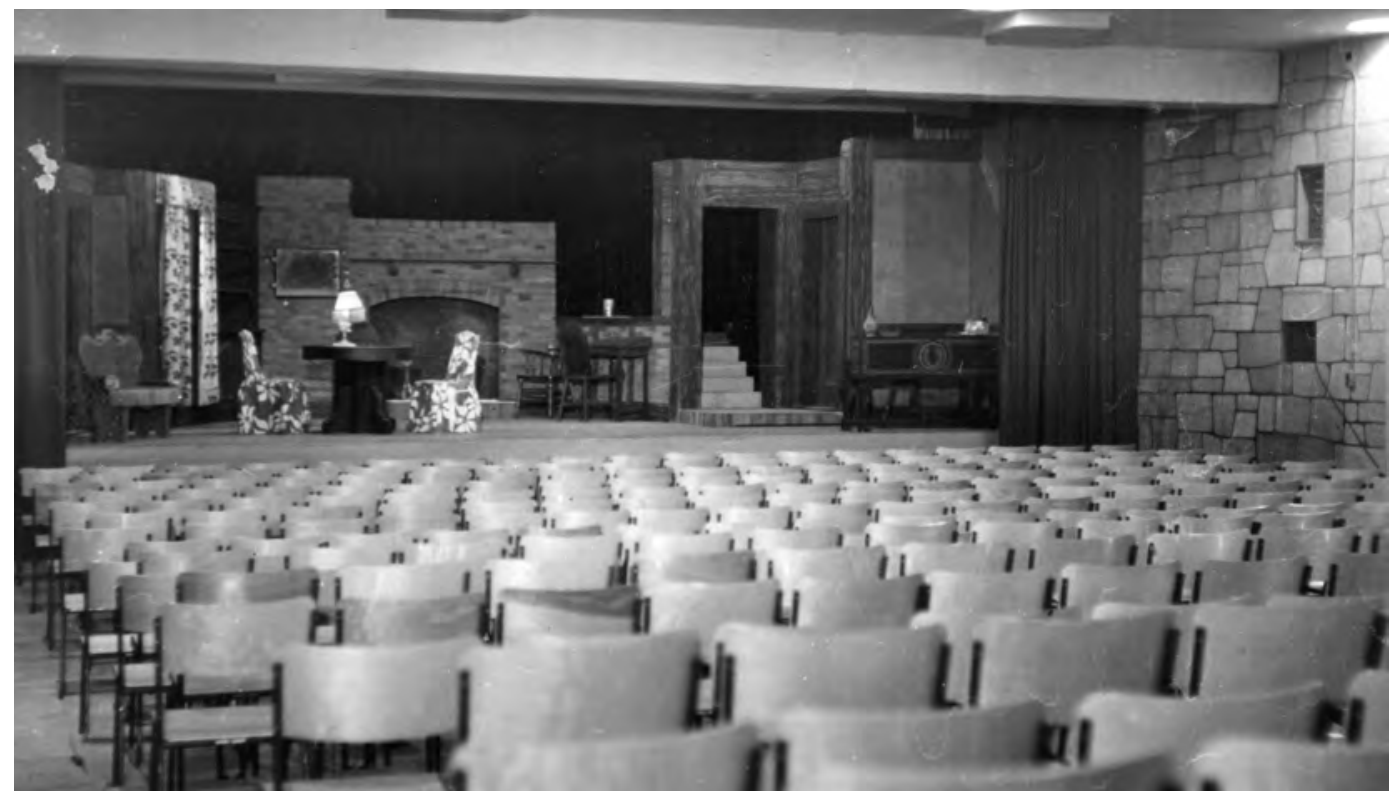

Photo of the Hangar building. Photo courtesy of the University of Saskatchewan, University Archives \& Special Collections, Photograph Collection, A-429. Photographer: Len Hillyard

Until the I970s, the four-year BA was seen as the basic degree to launch graduates in multiple directions. In the decades following, the BFA rapidly superseded it in many Canadian universities as the degree most aligned with the rapid post-war evolution of the Canadian theatre into professionalism. Positively, the change reflected the necessity for conservatory-style programs better designed to prepare students for more clearly defined career tracks in theatre (Stuart and Stuart 325-30). Less positively, as Scott and Nichols have suggested, its dominance to the exclusion of the older liberal arts stream seems to have been just as driven in recent decades by the corporatization of university culture and the financial pressure on universities to cull programs that are not producing hard "measurables" in terms of job-training: i.e., the number of graduates produced who successfully enter field-related careers after graduation. 


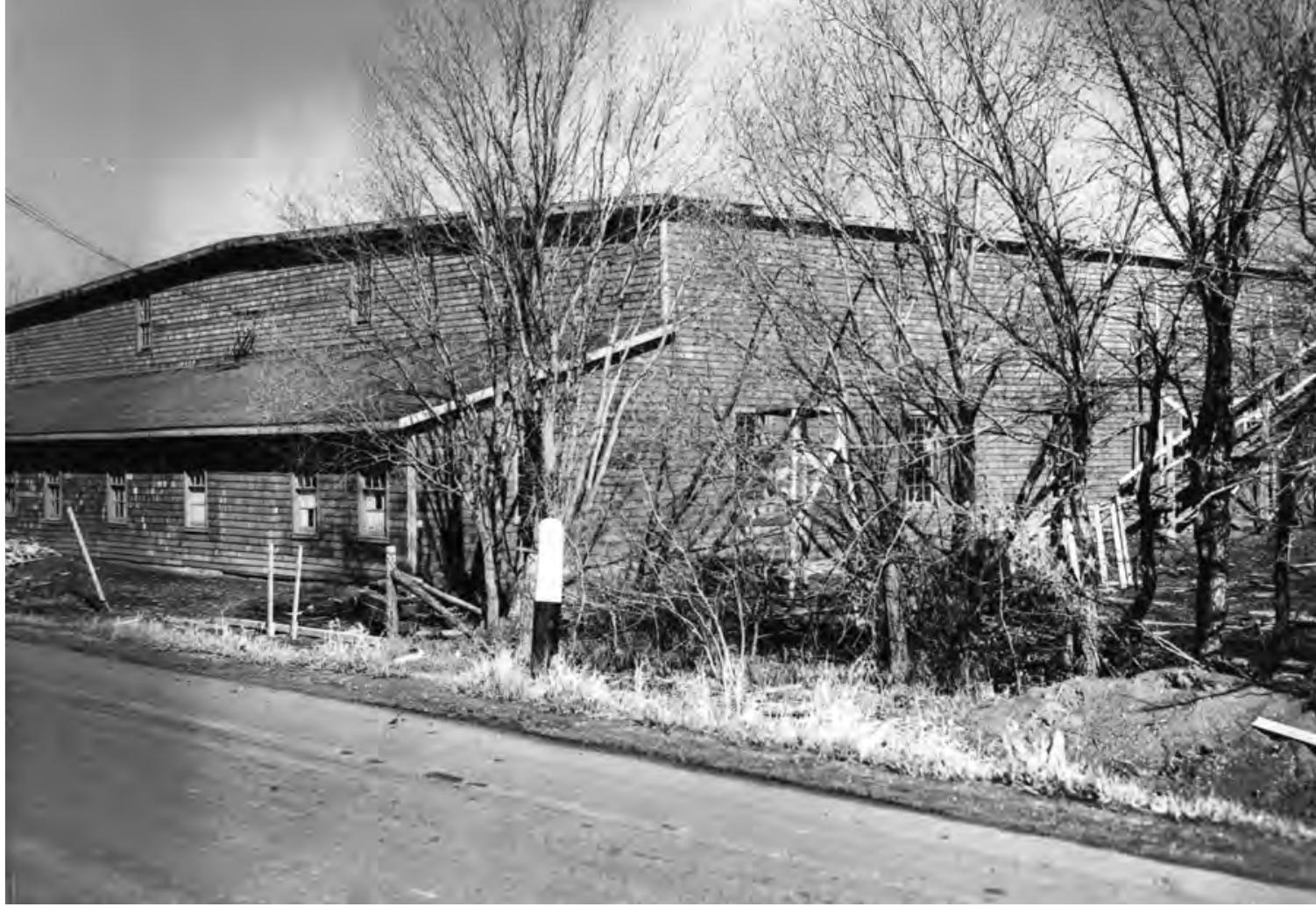

Photo of the Hangar building. Photo courtesy of the University of Saskatchewan,

University Archives \& Special Collections, Photograph Collection, A-6805

At our university, the danger of not correctly identifying what liberal arts training does was made manifest during the TransformUS process of 2013-I4; a recommendation was made not only to cut all but one of the Drama BA programs, but also to limit the overall number of $\mathrm{BA}$ programs campus-wide on the grounds that the BA was an obsolete or inefficient degree that did not produce "results." Fortunately, the move was reversed when it was discovered (I) that the BA degrees and the courses supporting them were actually very cost-efficient, bringing in more money than they expended, and (2) that students were still combining the $\mathrm{BA}$ with other forms of professional training to increase their chances of making it in a tight job market.

As regards Drama specifically, over 2OI4-I5, I did a survey of my 200-level theatre history class asking about the relevance of the BA degree in a department where the BFA was now the norm. The class of forty-seven students listed the following reasons for taking a BA degree (some listed more than one reason):

General interest 20

Pre-professional program to Design/Acting I8

Direct career opportunities afterwards $\quad$ I8

Combine with a second degree $\quad 22$

Other

Most spoke favorably on the flexibility of the degree as a starting place to move in a variety of directions: either further into drama training, or into alternative employment, training, or self-enrichment opportunities. Scott suggests law, and Blum suggests dramaturgy, as promising post-degree directions for graduates at Lethbridge. Here at Saskatchewan, teaching 
has been the route most eagerly pursued by drama graduates since the i940s. Historically, many early Western Canadian drama programs came into existence to train educators to handle the new curricular courses in the fine arts being offered in the schools: today, that route remains even more relevant in a world where an increasing array of specialized educational streams continue to proliferate, many specifically tailored to help develop formerly marginalized populations into full citizens of an increasingly diverse world.

One wonders if possible new directions are suggested by those old-and new-opportunities for combining theatre training with education and citizenship. Given drama's ancient connection to the religious, educational, and civic life of its community, especially during the classical and medieval periods, perhaps there is something to be learned from the way some religious colleges have dealt with a similar challenge of "relevance." Historically, many colleges or universities were church-affiliated, combining theological training with a liberal arts education to produce candidates for the ministry and a knowledgeable laity. How have they dealt with a university system that is now far more secular, professional, and utilitarian than it was when the colleges were started?

Newman Theological College in Edmonton offers an intriguing system of interconnected certificates, diplomas, and degrees, both on-line and on-campus, at the undergraduate and graduate level. There is something for everyone: from members of the public-Catholic and non-Catholic alike - who want to know more about aspects of Catholicism and get some accreditation for it; to those interested in pursuing a liberal arts degree in religious studies at lower or more advanced levels; to those who want to pursue a theological degree for professional purposes to pursue a career in academia, social work, or the ministry. Just as impressively, the work done to complete a lower level certificate or diploma can usually be credited towards a more intensive program if interest leads you in that direction. In connection to this, a further intriguing revelation from the 2013-I4 survey was the number of students within and outside the department (22) who expressed an interest in taking a certificate in Theatre History - if we were to package a selection of our academic courses in that wayas a supplement to other degrees/programs they were already taking. The Newman model suggests that rather than fragmenting existing degree programs, certificates may potentially feed them.

Beyond continuing to produce versatile career professionals for the theatre and the ever-expanding realm of electronic media, I would suggest, with my colleagues, that drama training also continues to do in the twenty-first century what it has done since antiquity: help create articulate, well-rounded citizens fully engaged in their world. Formal citizenship involves being legally recognized and admitted to membership in a given community and consequently being vested with "the rights, privileges, and duties" of citizenship. However, according to Dictionary.com, citizenship is also a state-of-being with significant human, moral and ethical imperatives, related to "the character of an individual viewed as a member of society" and their "behavior in terms of the duties, obligations, and functions of a citizen."

Again, the justification for drama in the classroom, and for training people to do it, comes down to issues of citizenship. In an age when media presence has never been more important, such training uniquely continues to teach poise, voice, movement, listening skills, an ability to think on one's feet, and confident public bearing and delivery. In addition to 
holistically developing human beings in and through action, who will be better prepared to be fully-engaged members of a rapidly changing world, play production arguably creates a social/political "state" in miniature where people are required to learn the art of "citizenship" in interactions with each other. If that argument was used in the I93Os as a way of teaching an increasingly diverse populace transformed by waves of immigration to "play" with each other in a controlled situation, as a dress rehearsal for real life (Armstrong 4), how much more true today, when we are becoming even more diverse in every way imaginable.

So when I say that the future of liberal arts drama programs - both in themselves and in conjunction with other programming - lies in developing the art of citizenship, and in avocations and vocations connected to citizenship training, I do not suggest it lightly. In closing, I will leave the last word to drama educator Harvey Ostroff, who in 2013 wrote a playful blog entitled, "Trudeau Should Be Proud of Being a Drama Teacher-and Harper Should Hire One": "People don't take drama classes to become actors, they take them to help realize their full potential; to become better communicators, better citizens, perhaps even better prime ministers."

\section{Works Cited}

Armstrong, Rev. George D. "Through the Study Window." Vegreville Observer, 22 Feb 1933: 4.

Microform.

“Citizenship.” Dictionary.com. N.p.: Lexico LLC., n.d. Web.

Newman Theological College. Official Site. wrewenewman.edu. Newman Theological College, n.d. Web. 30 Dec. 2017.

Ostroff, Harvey. "Trudeau Should Be Proud of Being a Drama Teacher-and Harper Should Hire

One." Huffington Post, 26 June 2013. n.p. Web. 30 Dec. 2017.

Stuart, Ross and Ann Stuart. "University Theatre." Later Stages: Essays in Ontario Theatre from the First World War to the 1970s. Ed. Ann Saddlemyer and Richard Plant. Toronto: U of T Press, 1997. 30532. Print. 